\title{
Early Dolomitization of Platform Carbonates and the Preservation of Magnetic Polarity
}

\author{
DONALD F. MCNEILL \\ Division of Marine Geology and Geophysics, Rosenstiel School of Marine and Atmospheric Science, \\ University of Miami, Florida
}

JOSEPH L. KIRSCHVINK

Division of Geological and Planetary Sciences, California Institute of Technology, Pasadena

\begin{abstract}
Results from a combination of techniques are presented to evaluate the nature of magnetization in shallowwater platform carbonates which have undergone recrystallization during early calcification and dolomitization. Magnetic grain separates, coercivity spectra, modified Lowrie-Fuller tests, magnetization efficiency, and magnetostratigraphic constraints indicate that the ultrafine-grained magnetite is preserved during early burial geochemical regimes, inversion from aragonite/high-magnesium calcite to low-magnesium calcite, and even pervasive dolomitization. These single-domain crystals are thought to occur as interacting multigrain clusters, some of which may exceed $1 \mu \mathrm{m}$ in diameter. These large clusters may help prohibit magnetic reorientation during diagenesis. Furthermore, during both fabric preserving and fabric destructive dolomitization, the ultrafine-scale replacement process restricts reorientation of the clusters, thus preserving depositional or early postdeposition magnetic orientation. This early dolomitization (matrix stabilization) may even help protect and extend the subsurface lifespan of the original polarity.
\end{abstract}

\section{INTRODUCTION}

Recognition of depositional or early postdepositional remanent magnetization in Tertiary and older shallow-water carbonates is becoming increasingly more critical. These results are now commonly used for magnetostratigraphic studies, paleomagnetic poles, and for timing of remagnetization related to major diagenetic events such as: dolomitization by relatively lowtemperature fluids; very early recrystallization; dolomitization by deep basinal fluids related to tectonic/orogenic events; dedolomitization; base metal emplacement; and early hematite formation from iron hydroxides [Horton et al., 1984; McCabe et al., 1984; McCabe et al., 1985; Elmore et al., 1985; Jackson and Van der Voo, 1985; Bachtadse et al., 1987; Hurley and Van der Voo, 1987; Jackson et al., 1988;]. In general, magnetic grains incorporated in shallow-water carbonates are often subjected to several carbonate diagenetic fluid and recrystallization regimes during deposition, initial dewatering, early compaction, cementation, mineralogic inversion, and recrystallization. Shallow-water limestones are especially prone to numerous diagenetic environments due to their proximity to sea level, with extremes ranging from an entirely marine fluid burial, to meteoric fluid exposure, to a complicated, often repetitive mixed fluid burial history. Secondly, the original mineralogies are often completely altered shortly after deposition, with complete recrystallization from an original aragonite/high-magnesium calcite mineralogy to low-magnesium calcite, and dolomite.

As a result of a better understanding of these carbonate diagenetic settings [Longman, 1980; Mcllreath and Morrow, 1990], and an expanding application of paleomagnetism to

Copyright 1993 by the American Geophysical Union.

Paper number $93 \mathrm{JB} 00353$.

0148-0227/93/93JB-00353\$05.00 shallow-water carbonates, this report will focus on the nature of magnetic remanence in rocks having undergone early, pervasive, near-surface dolomitization. We will address the question of magnetic grain preservation through recrystallization, and whether the magnetic grains are susceptible to reorientation during the recrystallization process. Samples for this study, and data on which comparisons are based, come from a larger magnetostratigraphic study where magnetic reversals have been correlated to the geomagnetic polarity time scale, with the aid of biostratigraphic markers [McNeill et al., 1988; McNeill, 1989]. The core borings for this study are from several different Bahamian platforms (Figure 1), and penetrate into Pliocene and late Miocene age rocks at their base. Core locations include Little Bahama Bank (GB-2, WC-1, SC-1); Great Bahama Bank (Unda, U-1, U-3); and Ocean Drilling Program site 632. Holocene samples were collected from Great Bahama Bank at Joulters Cay, Andros tidal flat (GBB-3), Tongue-of-the-Ocean (GBB-4), and Lee Stocking Island. Magnetization in shallow-water rocks which have undergone very early dolomitization (within 1-2 m.y. postdeposition) are of especial interest since (1) these rocks have undergone several (minimum of two) of the common carbonate diagenetic environments (initial burial, normal marine fluids, freshwater vadose and phreatic, mixed marine and freshwater); (2) they may provide a mineralogically stable matrix for the magnetic remanence carriers which could help extend the lifespan of the depositional magnetization, shielding it from complete destruction or remagnetization; (3) they comprise a large portion of late Tertiary carbonate platforms and atolls which contain a rich archive of sea level and regional depositional events; and (4) there are similar deposits in the ancient record that may contain important paleomagnetic poles if an early magnetization can be confirmed.

\section{Laboratory Methods}

All rock-magnetic and magnetostratigraphic measurements were conducted at the California Institute of Technology using a $2 \mathrm{G}$ 


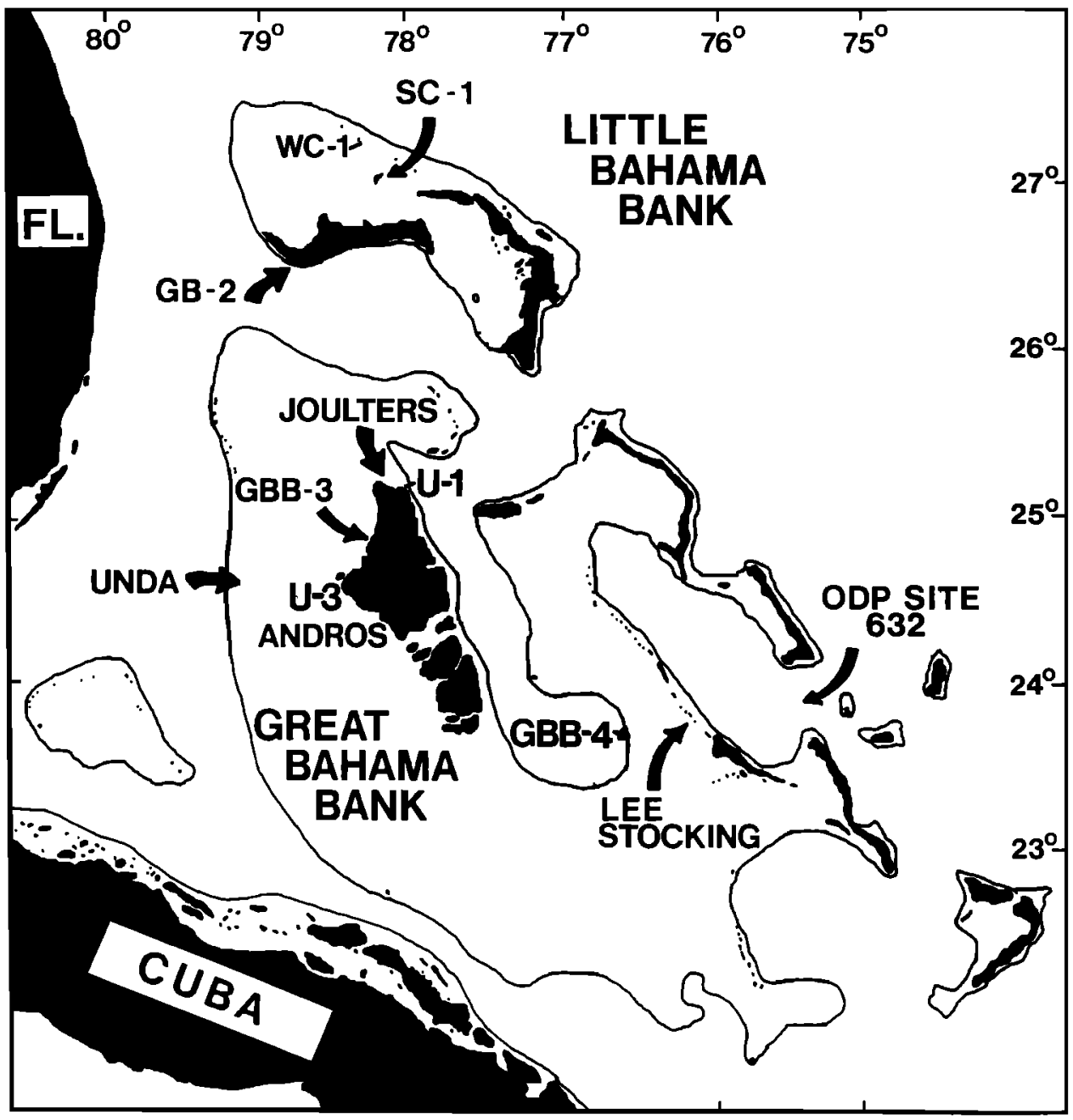

Fig. 1. Location of core borings containing limestone and dolomite, and sediment samples used in this study. Core borings include GB-2, WC-1, SC-1 from Little Bahama Bank; cores Unda, U-1, U-3 from Great Bahama Bank; and Ocean Drilling Program site 632 in Exuma Sound. Holocene sample localities include Joulters Cay ooid shoal, Andros tidal flat (GBB-3), Tongue-of-the-Ocean periplatform (GBB-4), and Lee Stocking Island platform sediments.

Enterprises 760 and SCT superconducting magnetometers, respectively. Additional measurement for the magnetization efficiency tests [Fuller et al., 1988] were done using a $2 \mathrm{G}$ Enterprises 755 magnetometer at the University of Miami. Coercivity and anhysteretic remanent magnetization (ARM) tests were both conducted on bulk samples, about $3 \mathrm{cc}$ in size. The magnetic separates were isolated following the technique of Chang and Kirschvink [1985], and examined on a Phillips 300 transmission electron microscope at $100 \mathrm{kV}$. Magnetic samples were collected from zones that have not undergone obvious massive dissolution and reprecipitation associated with meteoric diagenesis. These thin, vertically restricted zones of obvious diagenesis, usually associated with subaerial exposure, included void filling calcite and secondary iron-oxides associated with ancient soil horizons (paleosols).

\section{Source of Magnetic Minerals and Carbonate Magnetostratigraphy}

Confirming the preservation of an original remanent magnetization and polarity data is critical to applying magnetic reversal stratigraphy to platform carbonates. In outcrop, both conventional field tests (such as fold tests, breccia tests, lateral polarity continuity, and reversal tests) and rock-magnetic tests can be used to characterize and assess primary versus secondary remanence. In core borings from recent carbonate platforms and atolls, the rock-magnetic tests become significantly more critical for assessing a primary remanence.

Several recent studies [McNeill et al., 1988; McNeill, 1990; Aissaoui et al., 1990] have suggested that biogenically formed magnetite is the primary remanence carrier in isolated, shallowwater carbonate settings. Definitive recognition of biogenic magnetite in sediments older than a few thousand years is often not possible due to destruction of the characteristic organic components of the bacteria, mainly the magnetosome and the break-up of crystal chains which contain progressively smaller crystals in the formative stages at the end of the chain. Recognition is however based on a combination of characteristics such as limited single-domain size range associated with known bacteria [Kirschvink, 1982; McNeill et al., 1988], a titanium-poor crystal composition, crystal shape, and orientation in chains (although rarely preserved in platform carbonates except for 3 to 4 grain chains, and bearing in mind that the separation technique may realign the grains in chains). Carbonate rocks shown to have been remagnetized, have authigenic magnecite grains significantly different to those from modern sediments and nonremagnetized 
limestone/dolomites. Magnetic grains in these carbonates occur as either: large $(1-100 \mu \mathrm{m})$ spheres [Wisniowiecki et al., 1983; Horton et al., 1984; Bachtadse et al., 1987; Elmore et al., 1987; McCabe et al., 1987; Hart and Fuller, 1988]; pyrite/magnetite spheres [Suk et al., 1990]; noninteracting single-domain grains of perhaps spheroidal morphologies [Jackson, 1990]; or as extremely fine-grained ( $<300 \AA$ ) magnetite near the superparamagneticsingle domain boundary [Jackson et al., 1992].

\section{Dolomitization Process}

The mechanism of recrystallization to dolomite, and the controlling factors of the resulting crystal type, remain somewhat of an enigma. Three general pathways to dolomitization (see below) are commonly invoked to explain the dolomite fabrics [Morrow, 1990]:

$$
\begin{gathered}
2 \mathrm{CaCO}_{3}+\mathrm{Mg}^{2+}=\mathrm{CaMg}\left(\mathrm{CO}_{3}\right)_{2}+\mathrm{Ca}^{2+} \\
\mathrm{CaCO}_{3}+\mathrm{Mg}^{2+}+\mathrm{CO}_{3}{ }^{2-}=\mathrm{CaMg}\left(\mathrm{CO}_{3}\right)_{2} \\
(2-\mathrm{x}) \mathrm{CaCO}_{3}+\mathrm{Mg}^{2-}+\mathrm{xCO}_{3}{ }^{2-}=\mathrm{CaMg}\left(\mathrm{CO}_{3}\right)^{2-}+(1-\mathrm{x}) \mathrm{Ca}^{2+}
\end{gathered}
$$

Each equation involves different formation conditions and reactant by-products, but most importantly contain volume changes. For example, a volume loss is experienced in equation (1), an increased volume in equation (2), and volume conservation can occur in equation (3) under certain conditions. Any volume change would be important with respect to potential magnetic grain reorientation and the inclination/declination record. Thus, the individual dolomitization mechanisms have some impact on the resulting dolomite fabric, with either fabric preserving or destructive types [Sibley, 1982; Dawans and Swart, 1988]. Photomicrographs of the different dolomite fabric types are shown by Dawans and Swart [1988]. The precursor mineralogy, rate of dolomite crystallization, and the precipitating fluid composition are thought to be the main controls of fabric preservation in fluid dominated systems [Lippman, 1973; Sibley, 1982]

Lippman [1973] and Folk and Land [1975] suggested that the magnesium content (ordering) was a reflection of crystallization rate, with poorly ordered and calcian dolomites forming at faster rates relative to the more ordered stoichiometric dolomites. Subsequently, Dawans [1988] and Dawans and Swart [1988] have suggested that facies/permeability controls influence the rate of crystallization. Thus, sediments possessing initially high permeabilities had access to greater fluid flow. The dolomitizing fluids in these sediments had a higher saturation relative to dolomite, but due to relatively rapid precipitation, produced a more calcian dolomite. Their data show a very distinct separation of the mol percent $\mathrm{MgCO}_{3}$ in fabric preserving mimetic dolomite $(42 \%-46 \%)$ and fabric destructive, microsucrosic dolomite (47\%$49 \%$ ). At the same time, sediments with more uniform textures and lower permeabilities would allow reduced fluid flows and a slower rate of dolomitization, thus more stoichiometric dolomite. Traditionally, most dolomitization models invoke a fluid dominated mechanism to account for dolomitization and dolomite textural types.

More recently, Maliva and Siever [1988] proposed a very different mechanism for mineral diagenesis, that of forced crystallization-controlled replacement. This mechanism is of considerable interest with respect to the preservation of magnetic grains since it invokes a very thin solution film at the replacement boundary. Nonhydrostatic stress resulting from the formation and growth of authigenic crystals (calcite or dolomite) in contact with the host phase minerals (aragonite, high-magnesium calcite, lowmagnesium calcite) drives the replacement process. The pressure the growing crystal exerts against the host phase is responsible for the host phase dissolution at the stressed face through a solution film (several nanometers thick) at the boundary. At the stressed contact host phase dissolution occurs through increased solubility resulting from increased Gibbs free energy. This mechanism is intriguing for fine fabric preservation in that the pore waters during dolomitization do not have to be undersaturated with respect to the host mineral. Several fundamental textural criteria have been presented to support this mechanism [Maliva and Siever, 1988]. These include preservation of grain/crystal contacts (fabric preservation), the presence of precursor crystal ghosts, and sometimes the presence of euhedral authigenic crystal faces in planar contact with unreplaced hosts. Clearly, the most important of these is the high degree of fabric preservation, especially across crystal boundaries, which suggests that no space gap existed between host dissolution and authigenic crystal precipitation. This fabric preservation suggests that the rate of host dissolution equaled the rate of authigenic precipitation.

The effect of pervasive recrystallization on magnetic grains maintaining their original remanent orientation is of particular interest for assessing the potential for remagnetization, reorientation and may even help constrain the mechanics of the replacement process. Clearly, two factors are important in retaining the initial magnetic orientation, the preservation of original magnetic grains, and restricted grain rotation during the recrystallization process.

\section{Remagnetization Associated With Dolomitization}

It is important to realize that dolomitization, resulting from several completely different mechanisms, can occur at almost any point along the diagenetic pathway. Several Paleozoic examples of remagnetization associated with regional dolomitization and tectonism have been reported [McCabe et al., 1983; Horton et al., 1984; Bachtadse et al., 1987; Jackson, 1990]. Remagnetization in these dolomites was thought to occur through hydrothermal and/or basinal fluids coeval with the dolomitization, as opposed to a very early dolomitization by near normal marine waters considered here. Hart and Fuller [1988] reported both preservation and destruction of primary remanence in a dolomitized bed of the Monterey formation. In this case, a chemical remanent magnetization associated with dolomitization (cements) occurred irregularly in the unit. In the Monterey, the lithologies, organic content, and fluid migration history are considerably more complicated than the almost pure carbonate discussed here, and may have aided in supplying and mobilizing iron.

As the mechanisms for dolomitization are highly variable (normal seawater, mixed fluids, hypersaline brines, deep basinal fluids, tectonic related thermal events), some recrystallization events (i.e. basinal fluids, hydrothermal) are likely to have considerably greater remagnetization capabilities than others. Very early dolomitization and calcification of predominantly aragonitic sediments may help retain the depositional polarity during subsequent shallow- and deep-burial carbonate diagenetic events. In the Bahamian dolomites, the main dolomitization event was thought to occur within 1-2 m.y. after deposition [Swart et al., 1987; McNeill, 1989] based on $\mathrm{Sr}^{87} / \mathrm{Sr}^{86}$ isotopic dates [Vahrenkamp and Swart, 1988]. Horton et al., [1984] described an interesting situation where Mississippian-aged carbonates show magnetic preservation related to carbonate mineralogy and were 
used to constrain the timing of dolomitization. Several types of dolomite were shown to retain a late Paleozoic magnetization with single-domain or pseudo-single-domain magnetite carriers. Limestones were shown however, to have been completely remagnetized bearing a Tertiary pole position. Second, work on the Lower Ordovician Oneota dolomite in the upper Mississippi River valley indicates that a very early magnetization is preserved in the dolomite [Jackson and Van der Voo, 1985]. The Oneota dolomite is thought to have been deposited within a 5 m.y. interval, and probably experienced dolomitization relatively early in its diagenetic history. The relatively quiet tectonic history of the region has probably partially contributed to this preservation of early magnetization. These reports suggest that both early and late dolomitization can help preserve the original and early remagnetized remanence from subsequent carbonate diagenetic changes. A similar mineralogically stable matrix (low magnesium calcite to dolomite) in the young Bahamian dolomites may serve a similar protective purpose. The average lifespan of primary single-domain magnetite is unknown at present, but would be dependent on burial, thermal effects, and diagenetic fluid regimes: it is apparent however that secondary single-domain magnetite can have an extremely long preservation history [Jackson, 1990]

\section{RESULTS AND DISCUSSION}

In order to address the effects of early carbonate recrystallization on magnetic remanence, several techniques have been employed: magnetostratigraphic constraints, intensity and inclination characteristics, examination of magnetic separates, modified Lowrie-Fuller tests, Cisowski tests, magnetization efficiency tests, and ARM tests. Results from these tests support the preservation of original magnetic grains and remanence through early calcification and dolomitization.

\section{Magnetostratigraphic Constraints}

The vertical sequence of Bahamian dolomites contain several polarity reversals that with biostratigraphic markers, are correlative to the geomagnetic polarity time scale. Since dolomitization is believed to occur within a fairly restricted time range (2.5-3.5 Ma) [Swart et al., 1987; Vahrenkamp and Swart, 1988], remagnetization would likely have resulted in a pervasively normal polarity sequence. This has shown not to be the case for Little Bahama Bank where correlation is possible in the dolomitized section across the platform in the Early Pliocene rocks (Gilbert reversed chron) [McNeill, 1989].

\section{Grain Extracts}

Magnetic grain separates extracted from both fabric preserving and fabric destructive dolomites contain ultrafine-grained singledomain magnetite as confirmed by transmission electron microscopy (TEM) (Figure 2) and electron diffraction. The single-domain grains have crystal dimensions and morphologies similar to known biogenic magnetites [McNeill et al., 1988; $M c N e i l l, 1990]$. The extracted grains usually occur in large (> $1 \mu \mathrm{m}$ ) multigrain clusters (Figure 2 and see McNeill et al. [1988]), however, often show no signs of the original bacterial chain configuration. Alternatively, the clusters are somewhat similar to single-domain magnetite aggregates found in colonial magnetotactic organisms, although these aggregates are only about $0.5 \mu \mathrm{m}$ in diameter. Magnetic grains extracted from cemented limestones and dolomites usually occur in some type of grain

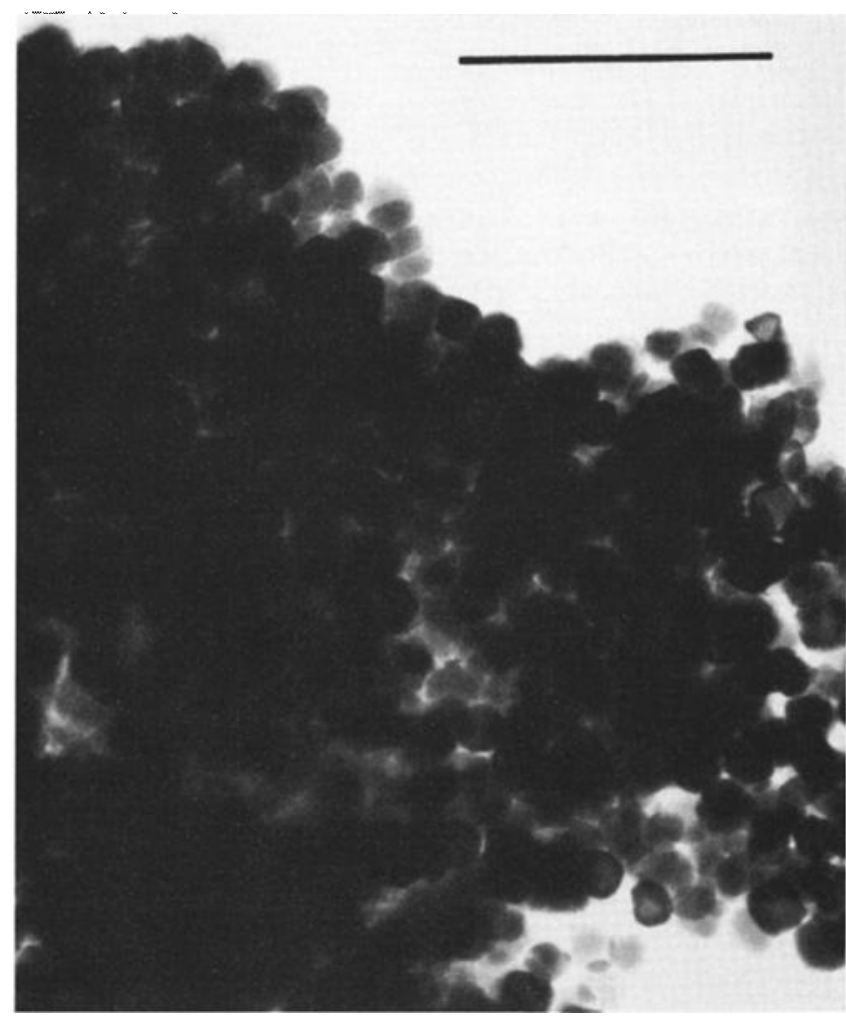

Fig. 2. TEM photomicrograph of single-domain magnetite crystals. The grains often occur as large clusters when separated from the carbonate matrix of loose sediment, limestones, and dolomites. The effect of the separation technique on clustering is uncertain. Sample from Ocean Drilling Program Leg 101, site $632-5 \mathrm{H}, 125-129 \mathrm{~cm}$. Scale bar $0.5 \mu \mathrm{m}$.

cluster, however, on a rare occasion a short chain configuration is observed in some separates. Grain clusters separated from Bahamian dolomites are similar in size (up to about $1 \mu \mathrm{m}$ ) and shape (irregular ovoid) to those shown by McNeill et al. [1988], also from the Bahamas subsurface. In addition, the cluster can sometimes be slightly more elongate and irregular (branching form) when fewer crystals are contained within the aggregate. Shapes similar to these have been reported from ancient limestones [Chang et al., 1987]. To date, no report of similar sized and shaped magnetite crystals have been reported from carbonates shown to have undergone remagnetization.

\section{Intensity Characteristics}

Magnetic intensity at natural remanent magnetization (NRM), and various alternating field (AF) and thermal demagnetization levels are similar for both the limestone and dolomitized sections (usually between $1.0 \times 10^{-8}$ and $5.0 \times 10^{-8} \mathrm{~A} \mathrm{~m}^{2} / \mathrm{kg}$ ) of a Bahamian core boring (Figure 3 ). The intensities are also comparable to those measured in Holocene carbonate sediment $\left(10^{-8}\right.$ to low $10^{-6}$ A $\mathrm{m}^{2} / \mathrm{kg}$ ) for similar depositional settings [McNeill, 1990; also unpublished data, 1991]. Remagnetized limestones and dolomites commonly exhibit much stronger intensities, about $10^{-2}$ to $10^{-5}$ $\mathrm{A} / \mathrm{m}$ ( $>10^{-3} \mathrm{~A} \mathrm{~m} / \mathrm{kg}$ NRM for comparison) [Johnson et al., 1984; Horton et al., 1984; Dunn and Elmore, 1985; Bachtadse et al., 1987; Tucker and Kent, 1988].

A second indication of original remanence, and nonremagnetization lies in the inclination record of the limestones and dolomites. The distribution of inclination angles is similar for both rock types, with a broad scattering of values usually ranging 

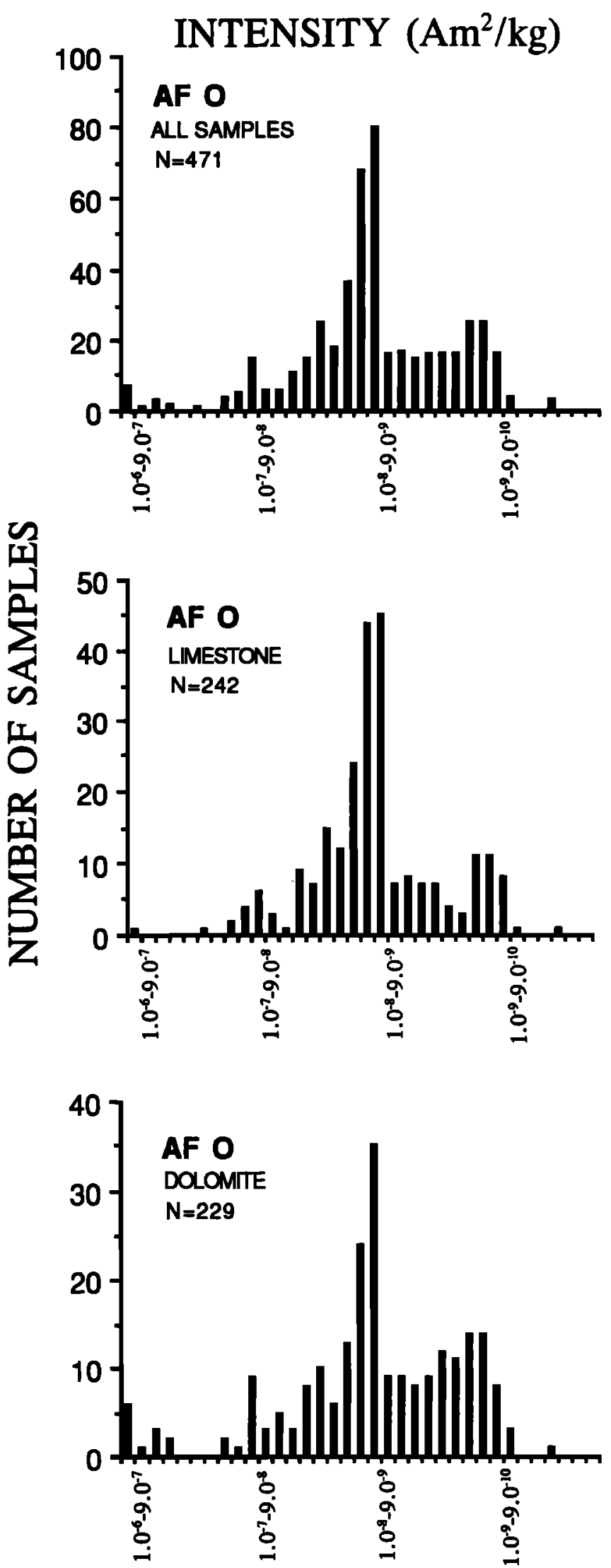

Fig. 3. Histograms of NRM magnetic intensity in limestones and dolomites from several Bahamian core borings. Nole similarity in intensity distribution between the two mineralogies. These intensity ranges overlap with values measured in sediments from modern carbonate depositional settings. from about $10^{\circ}$ up to $60^{\circ}$. This range of inclinations is consistent with some relatively young carbonates $(125 \mathrm{kyr}$ oolitic Miami Formation) composed of aragonite and low magnesium calcite in several $0.5 \mathrm{~m}$ thick beds, thought to have been deposited within several thousand years, with varying amounts of subsequent bioturbation (Figure 4). These results are inconsistent with pelagic limestones containing fine-grained magnetite, and likely reflect differences in the nature of carbonate deposition. Deposition of platform carbonates is often punctuated as compared to the more consistent, low accumulation rate, time-averaged record in pelagic limestones. This diversity of depositional environments, and associated physical processes, is interpreted to give rise to the wide-range of inclinations, and is not specific to predominantly biogenic remanences.

Likewise, precision parameters $(\mathrm{k})$ between the young Miami formation ( $k=18)$ and the Bahamian dolomitic rocks (mean $k=12)$ are within the same range (using method of Kono [1980]). The k values for remagnetized carbonates [McCabe et al., 1984; Jackson et al., 1988] are usually, although not always, significantly higher than the Bahamian carbonates. These low $\mathrm{k}$ values in Cenozoic carbonates can be interpreted as either preservation of the original magnetization representing a secular variation signal from punctuated deposition, or one which has been affected by various physical processes before and after signal "lock-in".

\section{Magnetization Efficiency}

Support for preservation of depositional or early postdepositional remanence also comes from comparing magnetization efficiency through a test recently described by Fuller et al. [1988] and Hart and Fuller [1988]. By comparing the ratio of $A F$ demagnetization of NRM versus the AF demagnetization of IRM (isothermal remanent magnetization), different efficiencies or magnetization regimes, can be isolated. Data from the Bahamas for several different types of dolomite indicates efficiencies similar to those of modern carbonate sediments, cemented calcite/aragonite rock, and completely lowmagnesium calcite limestones (Figure 5). The positioning along the same slope confirms a uniform remanence type and preservational history.

\section{Coercivity and Modified Lowrie-Fuller Tests}

Coercivity spectra and the ARM Lowrie-Fuller test for dolomites, low-magnesium calcites, aragonite-low magnesium calcite, and aragonite bearing rocks and sediment all exhibit similar characteristics (Figure 6), supporting a single-domain mineralogy that is preserved through several stages of diagenesis. Using the criteria determined by Cisowski [1981] the dominant remanence carrier is single-domain magnetite. In addition, the coercivity spectra are almost identical to the ultrafine-grained magnetite standard and Holocene carbonate sediments (Florida Keys) measured by Chang et al. [1987]. The coercivity patterns reflect a combination of interacting single-domain particles (confirmed by TEM examination) and partial oxidation of the magnetite grains. Relatively broad coercivity ranges (10-150 mT) for both the limestone and dolomite are indicative of partial grain corrosion or grain oxidation (Figure 6), perhaps to maghemite [Heider and Dunlop, 1987; Vali and Kirschvink, 1989]. In the separated crystals, this partial oxidation is represented by a fuzzy, rounded crystal boundary likely composed of maghemite. The significance of maghemite in Bahamian dolomites for carrying magnetic remanence has not yet been quantitatively assessed. 

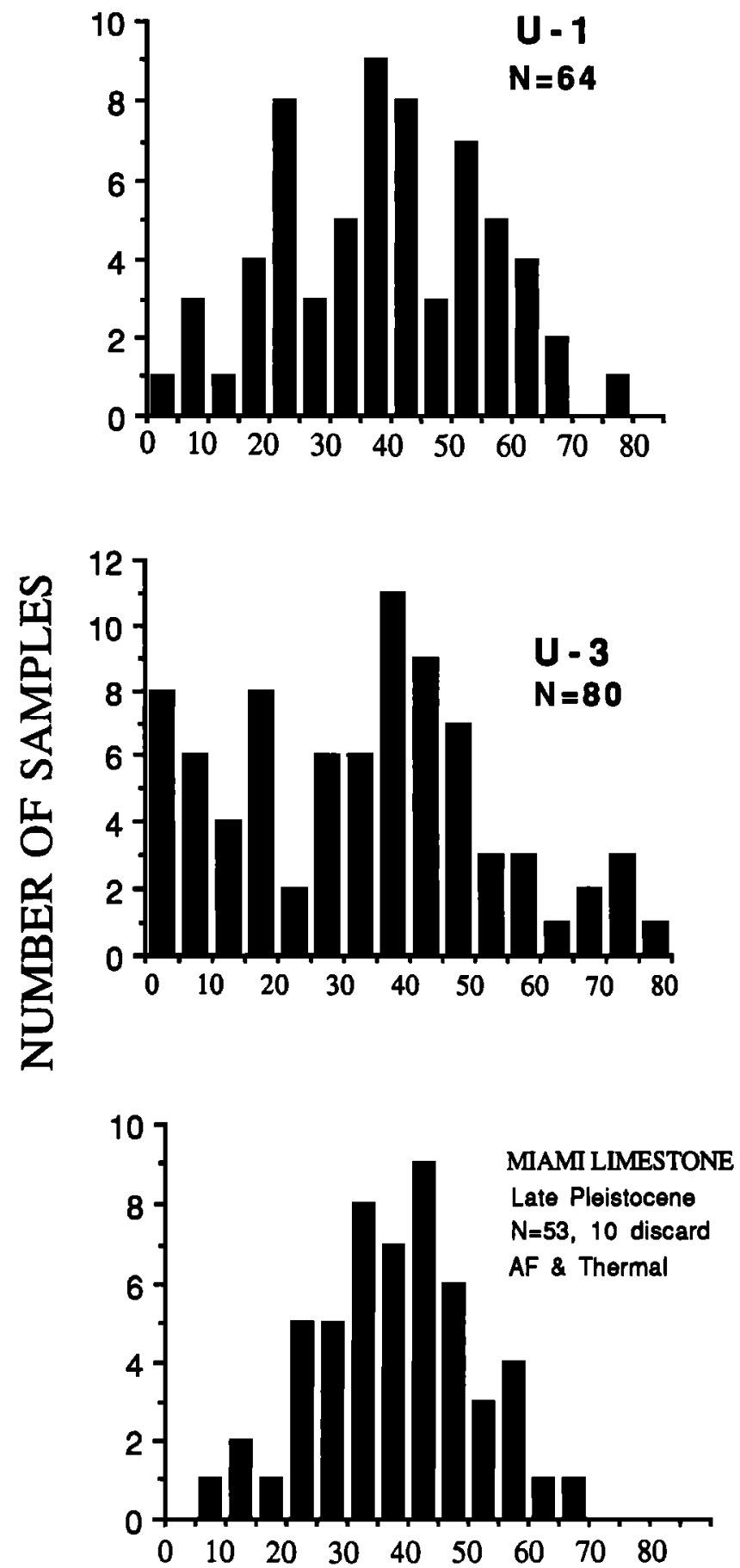

\section{INCLINATION (Degrees)}

Fig. 4. Histogram of inclination angles after principal component analysis from the upper $60 \mathrm{~m}$ from two cores (U-1 and U-3) on the northern end of Andros Island, Bahamas, and those from several beds within the late Pleistocene Miami Formation. The wide range of inclinations seems to be characteristic of late Tertiary and Quaternary Bahamian carbonates and likely represents the intermiltent nature of platform deposition, bioturbation, lithification, and the associated changes in morphology of the finegrained magnetite.

Remanence measurements after chemical treatment to dissolve maghemite suggests that it plays a partial, although minor role in total remanence for Bahamian dolomites. For example, in a corc from San Salvador, Bahamas, magnetic intensity at the NRM level, after AF and thermal demagnetization, shows no consistent decrease with depth which would suggest progressive maghemitization [McNeill et al., 1988]. The intensity values, do however, contain considerable downcore sample-to-sample variations which may represent bed-scale differences in magnetite oxidation and maghemite formation. Thermal sources or a thermal gradient that would enhance maghemite formation, are not thought to be significant in these shallow settings. Detailed facies/dolomite fabric and maghemite relationships remain to be determined.

The coercivity values (intersection of IRM curve and AF demagnetization of IRM, Figure 7) for Bahamian dolomites average $27.8 \mathrm{mT}(\mathrm{n}=13$, standard deviation $\nabla=4.8$ ) as compared to limestone at $30.1 \mathrm{mT}(\mathrm{n}=19, \nabla=5.2)$ and loose sediment at $38.6 \mathrm{mT}(n=10, \nabla=7.54)$. The higher coercivity average for unconsolidated, uncompacted sediments reflects a combination of rapid submarine cementation, perhaps helping to preserve a less interacting grain configuration, and lack of grain oxidation. The similarity between the limestone and dolomite coercivity values suggest a common preservational history. Upon initial dewatering and burial many of the loose sediments already approach the cemented rock values.

The percent sIRM at the intersection of IRM acquisition and AF decay curves ( $R$ value) can be used as an indicator of magnetostatic interacting behavior [Cisowski, 1981; Moskowitz et al., 1988]. For limestone and dolomite, percent sIRM at crossover values range from $26 \%-39 \%$, considerably lower than the ideal $50 \%$ often measured in less interacting single-domain magnetite extracts and unconsolidated sediment [Chang et al., 1987; Moskowitz et al., 1988; Vali and Kirschvink, 1989].

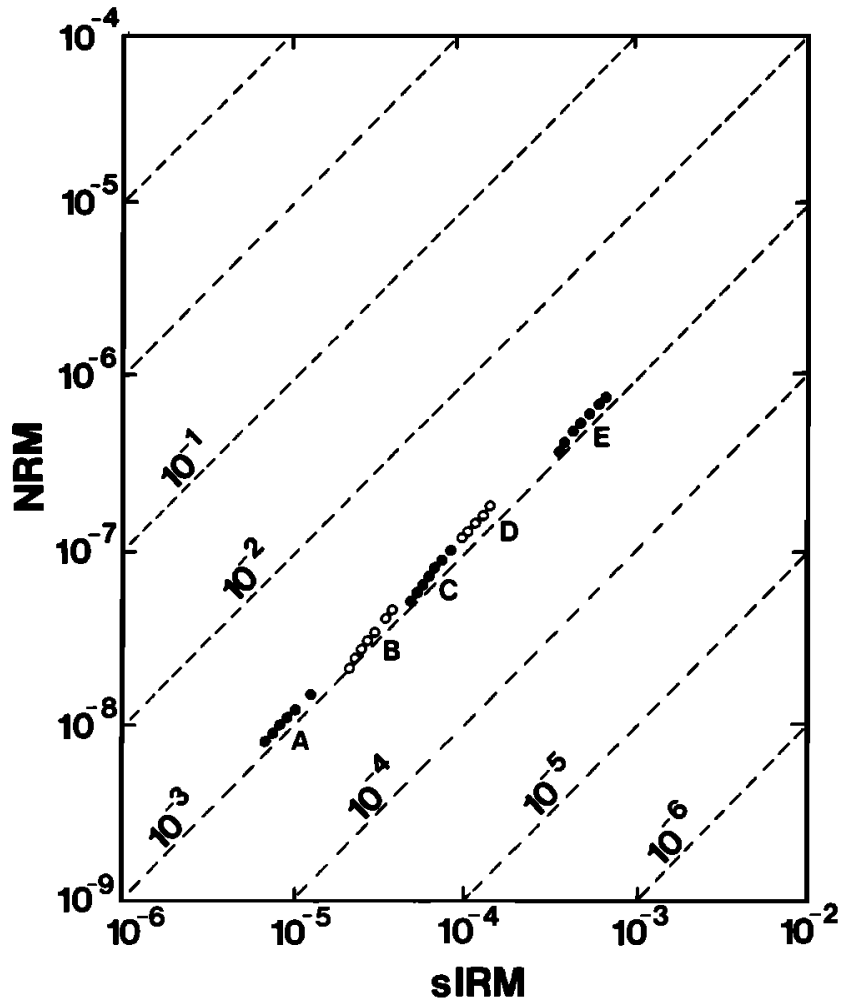

Fig. 5. Results of a test of magnetization efficiency devised by Fuller $e$ al. [1988] which examines the AF demagnetization ratios of the NRM and IRM. Values include unconsolidated Holocene sediments (C,D), calcitic limestone (A), and both fabric preserving (E) and fabric destructive dolomite (B). Magnetization along the $10^{-3}$ ratio line suggests a common source and preservation in the recrystallized rocks. 

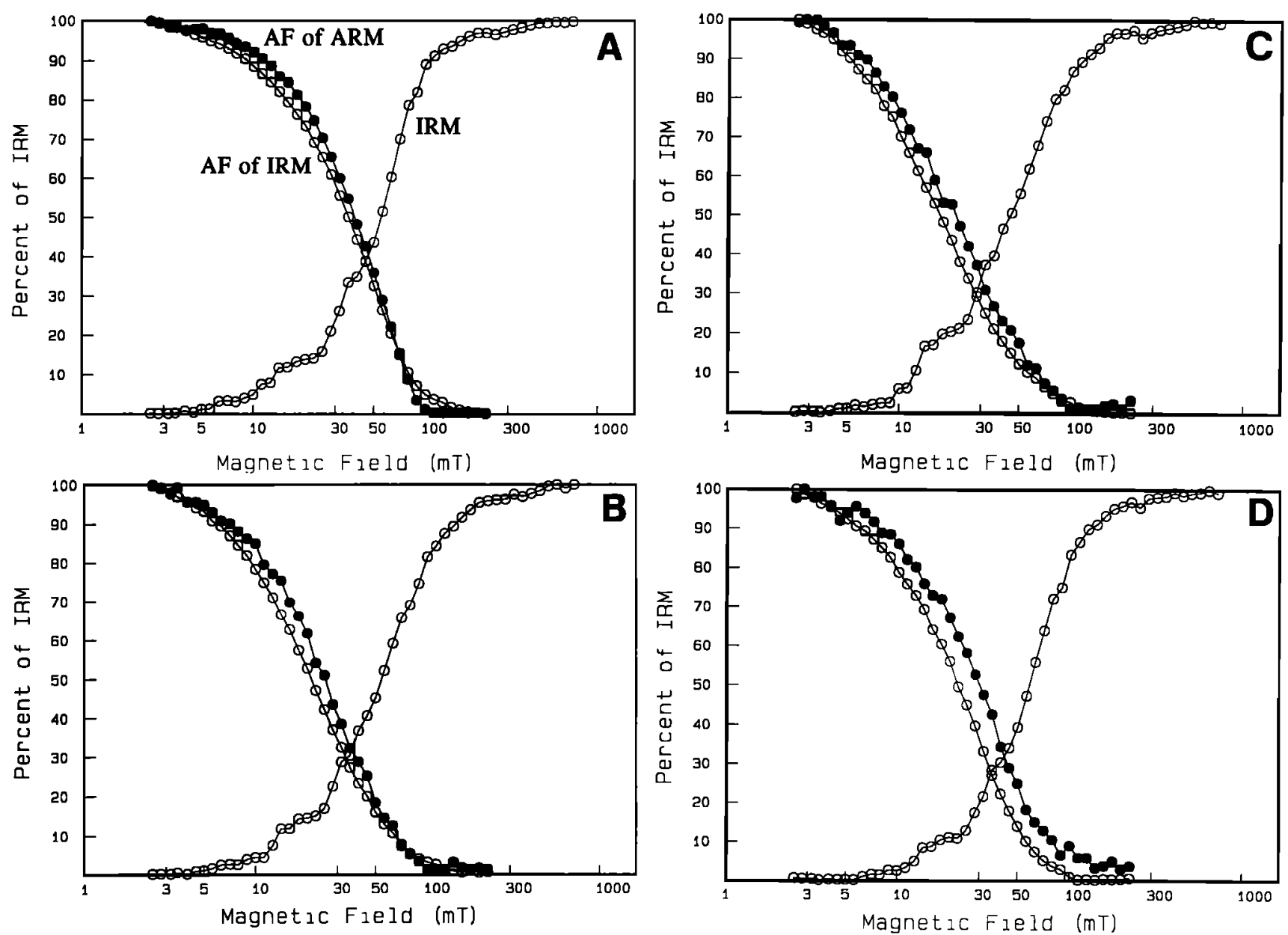

Fig. 6. Coercivity spectra for limestones and dolomite: $(a)$ modern submarine cemented sediments, Joulters Cay Bahamas; $(b)$ calcitic limestone, core UNDA, $28.8 \mathrm{~m}$; $(c)$ fabric preserving dolomite from core GB-1, $74.3 \mathrm{~m}$; and $(d)$ fabric destructive dolomite from San Salvador, $96 \mathrm{~m}$.

Modern carbonate sediments exhibit a slightly higher $\mathrm{R}$ cross-over value than the limestone and dolomite, likely the result of less grain interaction [Moskowitz et al., 1988; Vali and Kirschvink, 1989] prior to dewatering, compaction, and cementation. It should be remembered that these values may be influenced by depositional facies controls that often dictate the original concentration of single-domain magnetite and its subsequent preservation/loss through reactive early burial conditions.

\section{MAGNETIZATION "LOCK-IN" AND RESISTANCE TO REORIENTATION}

The location and size of the magnetic grains within the carbonate fabric is especially intriguing in light of potential preservation through multiple recrystallization events. Since physical separation of the ultrafine-grained magnetite crystals from the rock likely destroys the natural size and morphology of composite grain clusters, until now it has been impossible to assess how the magnetization resists diagenetic reorientation.

A test originally described by Cisowski [1981] and recently calibrated with biogenic magnetite crystals, and reported by Diaz Ricci et al., [1991] and McNeill et al., [1991], compares the ARM/maxIRM moment ratio at ARM fields up to $2.0 \mathrm{mT}$ in order to elucidate the interacting/non-interacting status of single-domain magnetite crystals. This ratio provides some indication of magnetic grain habit after "lock-in", however, it does not provide any constraints on the size of the specific clusters. This test, calibrated with end members of strongly interacting single-domain magnetite crystals in chiton teeth (responding magnetically as multidomain) versus fixed, noninteracting chains of single-domain crystals from cultured magnetotactic bacteria, indicates that much of the magnetite within the carbonate rock is tied up as interacting multigrain clusters (Figures 2 and 8). Many of the clusters separated from the carbonate are in excess of one micrometer, although the effects of separation on creating such clusters are still unknown.

Single-domain grain clusters may result naturally in the magnetosomes of magnetotactic bacteria [Towe and Moench, 1981] and in colonial magnetotactic organisms [Lins de Barros and Esquivel, 1985], or are perhaps formed during the decay of the organic membrane containing the chain(s) of magnetite crystals. Alternatively, postdepositional physical processes acting on the sediment [Verosub, 1977] may help promote grain clustering. In platform carbonates, the combination of initial dewatering, compaction, and burrowing both before and after dewatering, may act to not only homogenize the sediments but may also provide an avenue for magnetic grain clustering. The data indicate (Figure 8 ) that clustering occurs sometime after the period of high water content $(>50 \%)$, and before and/or during initial cementation. Thus, the post lock-in ARM test indicates a strong interaction of magnetite grains for the cemented limestone and dolomite, but little to moderate interaction in the carbonate sediments (Figure 8). 


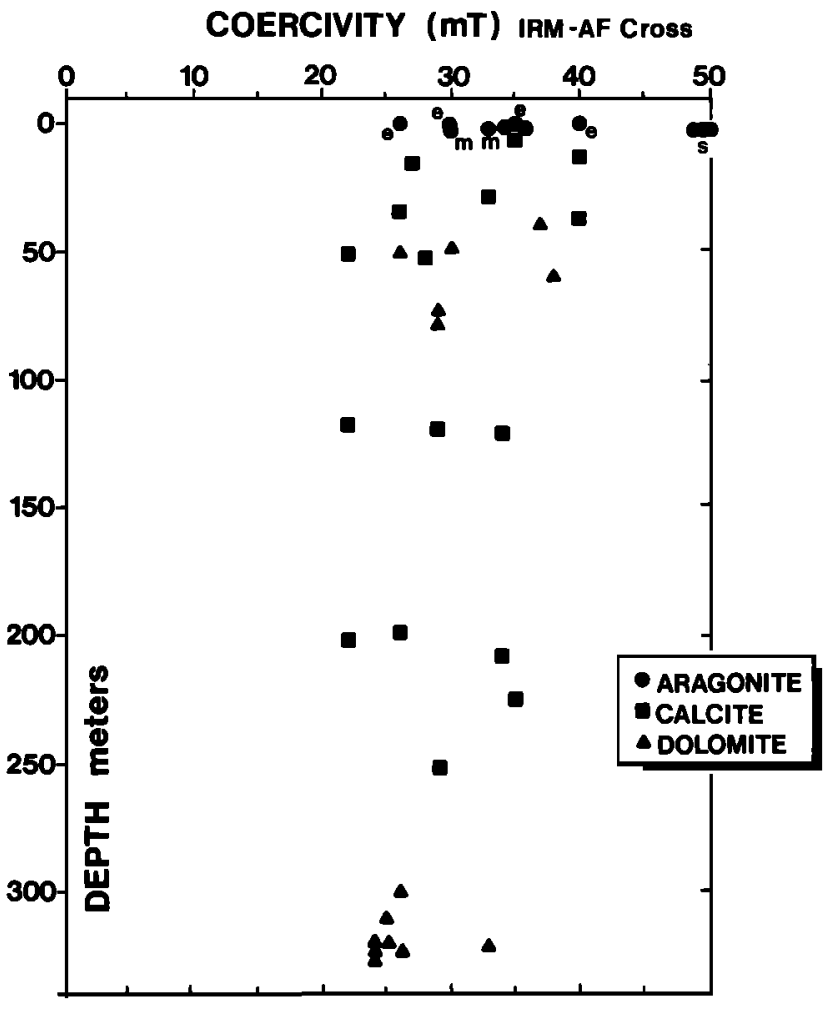

The capability of a limestone unit to resist grain reorientation is interpreted to stem from a combination of the larger multigrain clusters and the fine scale of the replacement process. The clustering of single-domain crystals is probably critical in retaining the original "lock-in" orientation through recrystallization because it increases the effective size of the magnetic grains within the carbonate matrix. This increased size, and perhaps an irregular shape, along with interacting magnetic forces within the cluster, assist in physical stability during recrystallization. The dissolution/reprecipitation process through either a fabric preserving migrating solution film at stressed boundaries, or fabric destructive recrystallization, must operate at such a fine scale through progressive replacement so as to disallow reorientation from rotation. Interacting grain clusters within the matrix structure are perhaps locked-in upon dewatering, and based on morphology and size are restricted from reorientation by carbonate grain contact inhibition. Thus, during dolomitization, the magnetic clusters are physically held in place by the carbonate grains although they are concurrently undergoing recrystallization.

Fig. 7. Coercivity values versus depth for varying mineralogies from Bahamian sediments and rocks. The limestone and dolonite fluctuate between 22 and $40 \mathrm{mT}$, the result of grain interactions and perhaps partial grain oxidation. Many of the Holocene sediments ( $e=$ eolianite, $m=$ mud) fall within this same range, except those which have undergone rapid submarine cementation (s).

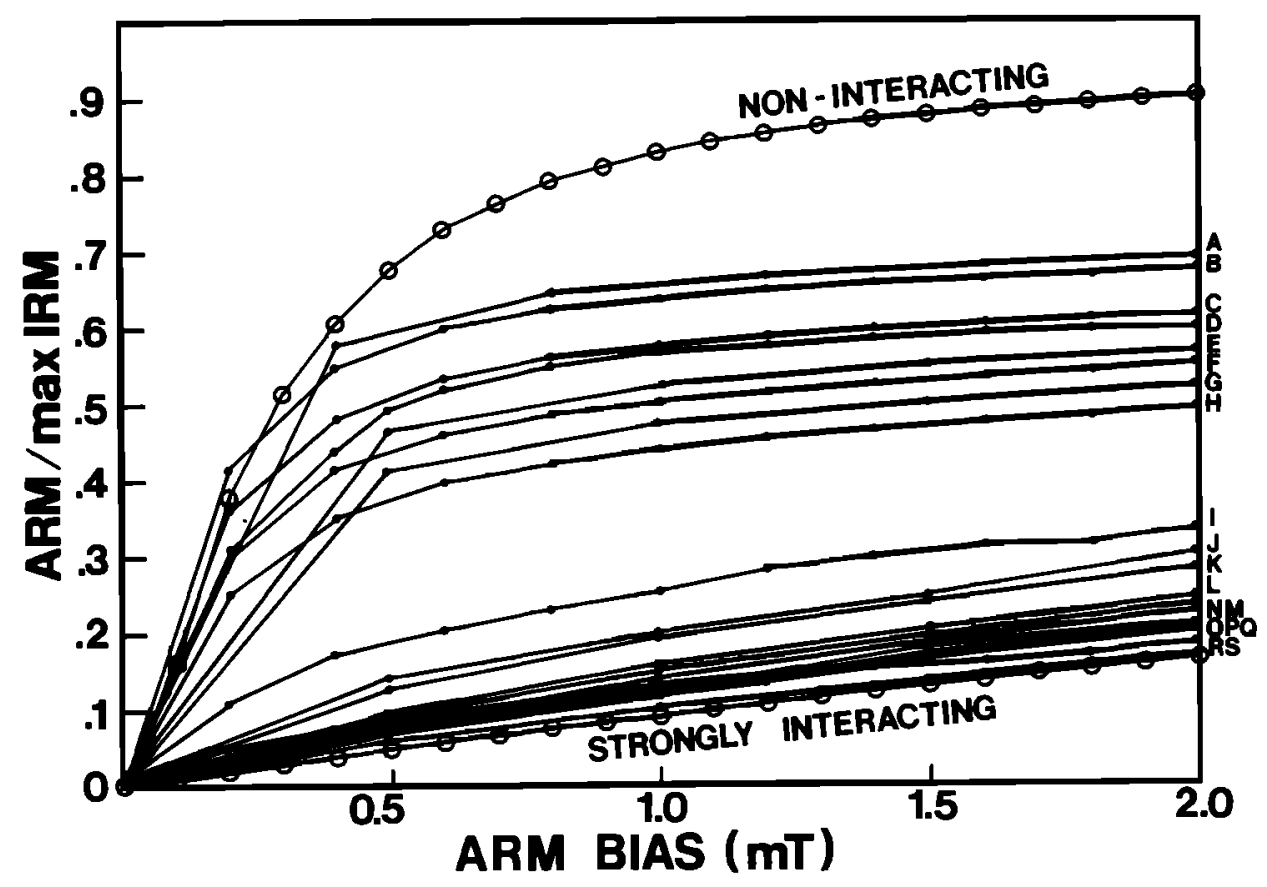

Fig. 8. Compilation of results from the ARM tests to assess the natural grain configuration in cemented rocks and sediments. All samples pass the modified Lowrie-Fuller test for single-domain crystals and indicate an interacting magnetic configuration. TEM examination of samples $A, G, H, L$ and $S$ have confirmed magnetic crystals in the single-domain size range. Samples A-H represent uncemented, unconsolidated, non-compacted carbonates, except for sample $G$ which is a submarine cemented hardground. Samples I-S cemented limestone and dolomite. A, GBB-2, Holocene peloid/mud, Great Bahama Bank (GBB), Bahamas; B, LSI-3, Holocene mud/oolite, Lee Stocking Island (LSI), Bahamas; C, GBB-6, Holocene periplat form mud, Tongue of the Ocean, Bahamas; D, GBB-3, Holocene tidal flat peloid mud, GBB, Bahamas; E, LSI-2, Holocene ooid sand, LSI, Bahamas; F, LSI-4, Holocene reef sands, LSI, Bahamas; G, Holocene submarine cemented ooids, Joulters, Bahamas; H, GBB-4, same as C; I, GB-2-198, Miocene dolomite, Little Bahama Bank (LBB), Bahamas; J, U-1055, Pliocene dolomite, core Unda, Bahamas; K, U-1055, Pliocene, core Unda, Bahamas; L, U-1050, Pliocene, core Unda, Bahamas; M, U-1062, Pliocene, core Unda, Bahamas, N, WC-167, Pliocene, LBB, Bahamas; O, U-1051, Pliocene, core Unda, Bahamas; P, GB-1-244, Miocene dolomite, LBB, Bahamas; Q, U-94.5, Pleistocene limestone, core Unda, Bahamas; R, U-678, Pleistocene limestone, core Unda, Bahamas; S, SC-162, Pliocene dolomite, LBB, Bahamas. 
So far, besides the ARM tests, confirmation of clusters would have to include locating and identifying single-domain crystal clusters within a sectioned carbonate rock: several attempts in Bahamian dolomites using the scanning electron microscope have been unsuccessful.

In the Bahamian dolomites, many sections of the core show an extremely high degree of minute fabric preservation, suggesting a forced crystallization-controlled replacement. Other core sections, mainly the fabric destructive (?) sucrosic dolomites either replaced similar calcite grains or directly replaced a fine-grained micritic texture. This type of dolomitization, which Sibley [1982] termed impingement replacement is also a contact initiated forced recrystallization [Maliva and Siever, 1988]. The critically important part of either of these dolomitization mechanisms remains that recrystallization in itself would restrict the free movement of these grain clusters, thus precluding magnetic reorientation. It is possible, however, that subsequent changes in the rock matrix, usually cementation, may contribute to magnetic grain clustering.

\section{CONCLUSIONS}

A combination of rock-magnetic test data, orientation data, magnetostratigraphic and $\mathrm{Sr}$-isotope age data, and magnetic separates suggests that ultrafine-grained single-domain magnetite can be preserved through early carbonate diagenetic regimes. Inversion to low-magnesium calcite and dolomitization shortly after deposition does not necessarily destroy or remagnetize the platform carbonates. More importantly, the single-domain magnetite bearing rocks can resist reorientation during the various recrystallization events due to the presence of relatively large multigrain clusters versus the ultrafine-grained replacement process operating at a thin solution film.

This recrystallization from metastable aragonite to either lowmagnesium calcite or dolomite shortly after deposition may indeed help prolong this weak, but stable remanence during platform subsidence and burial in marine fluids. The window of remanence preservation will vary considerably depending on subsequent exposure to basinal fluids, excessive geothermal gradients during burial, or dedolomitization associated with reemergence.

Acknowledgments. This study was made possible through the partial support of NSF grants EAR-8817060 and EAR-9005354 to DFM. Several new dolomite samples were available from a recently drilled core on Great Bahama Bank supported by the NSF grant OCE-8917295 and the industrial partners. The Ocean Drilling Program made samples available through request 11921A. The RSMAS Paleomagnetic Laboratory was made possible through NSF Grant EAR-8804957 and the W.H. Keck Foundation. Constructive reviews by D. Elmore, an associate editor, and an anonymous reviewer are acknowledged for improving the manuscript. A contribution from the Rosenstiel School of Marine and Atmospheric Science. Contribution 5185 from the California Institute of Technology.

\section{REFERENCES}

Aissaoui, D.M., D.F. McNeill, and J.L. Kirschvink, Magnetostratigraphic dating of Mururoa atoll and global eustasy, Earth Planet. Sci. Lett., 97, 102-112, 1990.

Bachtadse, V., R. Van der Voo, F.M. Haynes, and S.E. Kesler, Late Paleozoic magnetization of mineralized and unmineralized Ordovician carbonates from east Tennessee: Evidence for a post-ore chemical event, $J$. Geophys. Res., 92, 14,165-14,176, 1987.

Chang, S-B.R., and J.L. Kirschvink, Possible biogenic magnetite fossils from the Miocene marine clay of Crete, in Magnetite Biomineralization and Magnetoreception in Organisms, edited by J.L. Kirschvink, D.S. Jones, and B.J. MacFadden, pp.647-669, Plenum, New York, 1985.
Chang, S.-B. R., J.F. Stolz, and J.L. Kirschvink, Biogenic magnetite as primary remanence carrier in limestone deposits, Phys. Earth Planet. Inter., 46, 289-303, 1987.

Cisowski, S., Interacting vs. non-interacting single-domain behavior in natural and synthetic samples, Phys. Earth Planet. Inter., 26, 56-62, 1981.

Dawans, J.M.L., Distribution and petrography of Late Cenozoic dolomites beneath San Salvador and New Providence Islands, the Bahamas, M.S thesis, 91 pp., Univ. of Miami, Coral Gables, 1988.

Dawan, J.M.L., and P.K. Swart, Textural and geochemical alternations in Late Cenozoic Bahamian dolomites, Sedimentology, 35, 385-403, 1988.

Diaz Ricci, J.C., Woodford, B.J., Kirschvink, J.L., and Hoffman, M.R., Alteration of the magnetic properties of Aquaspirillum magnetotacticum by a pulse magnetization technique, Appl. and Environ. Microbiol., 57, 32483254, 1991.

Dunn, W.J., and R.D. Elmore, Paleomagnetic and petrographic investigation of the Taum Sauk Limestone, southeast Missouri, J. Geophys. Res., 90 , $11,469-11,483,1985$.

Elmore, R.D., W. Dunn, and C. Peck, Absolute dating of dedolomitization by means of paleomagnetic techniques, Geology, 13, 558-561, 1985.

Elmore, R.D., M.H. Engel, L. Crawford, K. Nick, S. Imbus, and Z.Sofer, Evidence for a relationship between hydrocarbons and authigenic magnetite, Nature, 325, 428-430, 1987.

Folk, R.L., and L.S. Land, $\mathrm{Mg} / \mathrm{Ca}$ ratio and salinity: Two controls over crystallization of dolomite, AAPG Bull., 59, 60-68, 1975.

Fuller, M., S. Cisowski, M. Hart, R. Haston, E. Schmidtke, and R. Jarrard, NRM:IRM(S) demagnetization plots: An aid to the interpretation of natural remanent magnetization, Geophys. Res. Lett. , 15, 518-521, 1988.

Hart, M., and M. Fuller, Magnetization of a dolomite bed in the Monterey Formation: Implications for diagenesis, Geophys. Res. Lett., 15, 491-494, 1988.

Heider, F., and D.J. Dunlop, Two types of chemical remanent magnetization during the oxidation of magnetite, Phys. Earth Planet. Inter., 46, 24-45, 1987.

Horton, R.A., Jr., J.W. Geissman, and R.J. Tschauder, Paleomagnetism and rock magnetism of the Mississippian Leadville (carbonate) formation and implication for the age of sub-regional dolomitization, Geophys. Res. Lett., $11,138-146,1984$

Hurley, N.F., and R. Van der Voo, Paleomagnetism of Upper Devonian reefal limestones, Canning basin, Western Australia, Geol. Soc. Am. Bull., 98, 138-146, 1987.

Jackson, M., Diagenetic sources of stable remanence in remagnetized Paleozoic cratonic carbonates: A rock magnetic study, J. Geophys. Res., 95, 2753-2761, 1990.

Jackson, M., and R. Van der Voo, A lower Ordovician paleomagnetic pole from the Oneota Dolomite, Upper Mississippi Valley, J. Geophys. Res., $90,10,499-10,461,1985$.

Jackson, M., C. McCabe, M.M. Ballard, and R. Van der Voo, Magnetite authigenesis and diagenetic paleotemperature across the northern Appalachian basin, Geology, 16, 592-595, 1988.

Jackson, M., W.W. Sun, and J.P. Craddock, The rock magnetic fingerprint of chemical remagnetization in midcontinental Paleozoic carbonates, Geophys. Res. Lett., 19, 781-784, 1992.

Johnson, R.J.E., R. Van der Voo, and W. Lowrie, Paleomagnetism and late diagenesis of Jurassic carbonates from the Jura Mountains, Switzerland and France. Geol. Soc. Am. Bull., 95, 478-488, 1984.

Kirschvink, J.L., Paleomagnetic evidence for fossil biogenic magnetite in western Crete, Earth Planet. Sci. Lett., 59, 383-392, 1982.

Kono, M., Statistics of paleomagnetic inclination data, J. Geophys. Res., 85 , 3878-3882, 1980.

Lins de Barros, H.G.P., and M.S. Esquivel, Magnetic microorganisms found in muds from Rio de Janeiro, in Magnetite Biomineralization and Magnetoreception in Organisms, edited by J.L. Kirschvink, D.S. Jones, and B.J. MacFadden, pp.289-309, Plenum, New York, 1985.

Lippman, F., Sedimentary Carbonate Minerals, 228 pp., Springer-Verlag, New York, 1973.

Longman, M.W., Carbonate diagenetic textures from near-surface diagenetic environments, AAPG Bull., 64, 461-487, 1980.

Maliva, R.G., and R. Siever, Diagenetic replacement controlled by force of crystallization, Geology, 16, 688-691, 1988.

McCabe, C., R. Van der Voo, D.R. Peacor, C.R. Scotese, and R. Freeman, Diagenetic magnetite carries ancient yet secondary remanence in some 
Paleozoic sedimentary carbonates, Geology, 11, 221-223, 1983.

McCabe, C., R. Van der Voo, M.M. Ballard, Late Paleozoic remagnetization of the Trenton limestone, Geophys. Res. Lett., 11, 979-982, 1984.

McCabe, C., R. Van der Voo, B.H. Wilkinson, and K. Devaney, A Middle/Late Silurian paleomagnetic pole from limestone reefs of the Wabash formation, Indiana, U.S.A, J. Geophys. Res., 90, 2959-2965, 1985.

McCabe, C., R. Sassen, and B. Saffer, Occurrence of secondary magnetite within biodegraded oil, Geology, 15, 7-10, 1987.

Mcllreath, I., and Morrow, D.W., Diagenesis, Geosci. Can., 4, 338 pp., 1990.

McNeill, D.F., R.N. Ginsburg, S.-B.R. Chang, and J.L. Kirschvink, Magnetostratigraphic dating of shallow-water carbonates from San Salvador, the Bahamas, Geology, 16, 8-12, 1988.

McNeill, D.F., Magnetostratigraphic dating and magnetization of Cenozoic platform carbonates from the Bahamas, Ph.D. thesis, 210 pp., Univ. of Miami, Coral Gables, 1989.

McNeill, D.F., Biogenic magnetite from surface Holocene carbonate sediments, Great Bahama Bank, J. Geophys. Res., 95, 4363-4371, 1990.

McNeill, D.F., Paschke, C.A., Kirschvink, J.L., Sauer, D., and Diaz Ricci, J.C., Implications for the nature and timing of magnetization in shallowwater carbonates: ARM test results, Eos Trans. AGU, 72 (44), Fall Meeting Suppl., 142, 1991.

Morrow, D.W., Dolomite, part 1, The chemistry of dolomitization and dolomite precipitation, Geosci. Can., 4, 113-124, 1990.

Moskowitz, B.M., R.B. Frankel, P.J. Flanders, R.P. Blakemore, and B.B. Schwart, Magnetic properties of magnetotactic bacteria, J. Magn. Magn. Mater., 73, 273-288, 1988.

Sibley, D.F., The origin of common dolomite fabrics: Clues from the Pliocene, J. Sediment. Petrol., 52, 1087-1100, 1982.

Suk, D., D.R. Peacor, and R. Van der Voo, Replacement of pyrite framboids by magnetite in limestone and implications for palaeomagnetism, Nature, 345, 611-613, 1990.
Swart, P.K., J. Ruiz, and C.W. Holmes, Use of strontium isotopes to constrain the timing and mode of dolomitization of upper Cenozoic sediments in a core from San Salvador, Bahamas, Geology, 15, 262-265, 1987.

Towe, K.M., and T.T. Moench, Electro-optical characterization of bacterial magnetite, Earth Planet. Sci. Lett., 52, 213-220, 1981.

Tucker, S., and D.V. Kent, Multiple remagnetizations of Lower Paleozoic limestones from the Taconics of Vermont. J. Geophys. Res., 15, 12511254, 1988.

Vahrenkamp, V.C., and P.K. Swart, Constraints and interpretation of ${ }^{7} \mathrm{Sr} /{ }^{* 6} \mathrm{Sr}$ ratios in Cenozoic dolomites, Geophys. Res. Lett., 15, 385-388, 1988.

Vali, H., and J.L. Kirschvink, Magnetofossil dissolution in a palaeomagnetically unstable deep-sea sediment, Nature, 339, 203-206, 1989.

Verosub, K.L., Depositional and postdepositional processes in the magnetization of sediments, Rev. Geophys., 15, 129-143, 1977.

Wisniowiecki, M.J., R. Van der Voo, C. McCabe, and W.C. Kelly, A Pennsylvanian paleomagnetic pole from the mineralized late Cambrian Bonneterre formation, southeast Missouri, J. Geophys. Res., 88, 6540$6548,1983$.

J. L. Kirschvink, Division of Geological and Planetary Sciences 170-25, California Institute of Technology, Pasadena, CA 91125

D. F. McNeill, Division of Marine Geology and Geophysics, Rosenstiel

School of Marine and Atmospheric Science University of Miami, 4600 Rickenbacker Causeway, Miami, FL 33149.

(Received June 26, 1992; revised January 20, 1993; accepted February 5, 1993.) 